F. Reprod. Fert. (1967) 13, 333-335

BRIEF COMMUNICATION

\title{
PRESERVATION OF PRIMATE SPERMATOZOA BY FREEZING
}

\author{
J. D. ROUSSEL AND C. R. AUSTIN \\ Delta Regional Primate Research Centre, Tulane University, \\ Covington, La., U.S.A.
}

(Received 29th September 1966)

As early as 1897 , Davenport found that human spermatozoa would survive freezing to $-17^{\circ} \mathrm{C}$, but little progress in the freeze-preservation of spermatozoa was made until 1949 when Polge, Smith \& Parkes reported that the use of glycerol made possible the revival of motility in fowl spermatozoa kept at $-79^{\circ} \mathrm{C}$ for long periods of time. Later, freeze-preservation of the semen of several animals became a routine procedure (see Sherman, 1964). Success, however, appeared to depend upon closely controlled rates of freezing and thawing, which demanded the use of specialized equipment. It was first shown by Sherman (1963) with human semen, and by Roussel, Kellgren \& Patrick (1964) with bovine semen, that successful freezing and storage of spermatozoa in liquid nitrogen vapour for indefinite periods of time could be achieved without instrumentation. The present report describes the employment of this procedure for primate semen.

Adult males of the following species were used: three Macaca mulatta (rhesus), two M. speciosa (stumptail), three Erythrocebus patas (patas), three Cercopithecus aethiops (African green) and two Pan troglodytes (chimpanzee). The animals were anaesthetized with phencyclidine (Sernyl) at a dose rate of $2 \mathrm{mg} / \mathrm{kg}$ intramuscularly. Semen samples were collected by a modification of the electroejaculation technique described by Weisbroth \& Young (1965): details of procedures, as applied to several different primates, together with observations on properties of the ejaculates obtained, are the subject of a separate report now in preparation. Immediately after collection, all samples were treated with $0.5 \%$ trypsin solution, which has been shown by Roussel \& Austin (1967) to bring about liquefaction of primate seminal coagulum without deleterious effect to the spermatozoa. A small sample was then removed for estimation of the proportion of spermatozoa showing progressive forward motility. The extender used consisted of $20 \%$ egg yolk (avian), $64 \%$ of a $3.0 \% \mathrm{w} / \mathrm{v}$ sodium glutamate solution in double glass-distilled water, and $14 \%$ glycerol (egg yolk-glutamateglycerol). Glutamate (sodium $\mathbf{L}-\alpha$-aminoglutarate) has been found to be a better buffer than sodium citrate for the storage of bovine semen at $5^{\circ} \mathrm{C}$ for long periods of time (J. D. Roussel, unpublished data). Semen was added to the extender in a ratio of $1: 10$ and equilibrated for $30 \mathrm{~min}$ at room temperature. 
The extended semen $(0.5 \mathrm{ml})$ was dispensed into $1.2 \mathrm{ml}$ glass ampoules and sealed with a semi-automatic sealer. Two ampoules were placed on each cane and lowered for $3 \mathrm{~min}$ into the neck of a Linde liquid nitrogen refrigerator (35B) containing 8 in. of liquid nitrogen. Then, the canes were lowered further into the refrigerator so that the bottom ampoule was about 2 in. above the liquid nitrogen, and left for $5 \mathrm{~min}$. Finally, the canes were placed in their assigned canister in the liquid nitrogen for 3 days. Frozen semen was thawed by placing ampoules in a $5^{\circ} \mathrm{C}$ water bath until thawing was complete, which generally took about $3 \mathrm{~min}$. The proportion of spermatozoa showing progressive forward motility was again assessed.

A summary of the pre-freeze and post-thaw motility and the survival rate observed is set out in Table 1 . The survival rate ranged from $37 \%$ to $75 \%$

TABLE 1

MOTILITY AND SURVIVAL RATE OF SPERMATOZOA IN SEMEN FROZEN IN LIQUID NITROGEN VAPOUR

\begin{tabular}{|c|c|c|c|c|c|}
\hline \multirow{2}{*}{ Species } & \multirow{2}{*}{ Animal No. } & \multirow{2}{*}{$\begin{array}{l}\text { No. of } \\
\text { samples }\end{array}$} & \multicolumn{2}{|c|}{ Per cent motility } & \multirow{2}{*}{$\begin{array}{l}\text { Per cent } \\
\text { survival }\end{array}$} \\
\hline & & & Pre-freeze & Post-thaw & \\
\hline Rhesus & $\begin{array}{l}108 \\
208 \\
204\end{array}$ & $\begin{array}{l}3 \\
3 \\
1\end{array}$ & $\begin{array}{l}48 \\
58 \\
60\end{array}$ & $\begin{array}{l}22 \\
32 \\
30\end{array}$ & $\begin{array}{l}46 \\
55 \\
50\end{array}$ \\
\hline Total and means & & 7 & 54 & 27 & 50 \\
\hline Stumptail & $\begin{array}{r}956 \\
1060\end{array}$ & $\begin{array}{l}1 \\
2\end{array}$ & $\begin{array}{l}40 \\
55\end{array}$ & $\begin{array}{l}15 \\
30\end{array}$ & $\begin{array}{l}37 \\
56\end{array}$ \\
\hline Total and means & & 3 & 50 & 25 & 50 \\
\hline Patas & $\begin{array}{l}226 \\
224 \\
932\end{array}$ & $\begin{array}{l}5 \\
1 \\
1\end{array}$ & $\begin{array}{l}47 \\
40 \\
40\end{array}$ & $\begin{array}{l}26 \\
20 \\
15\end{array}$ & $\begin{array}{l}55 \\
50 \\
37\end{array}$ \\
\hline Total and means & & 7 & 45 & 23 & 51 \\
\hline African green & $\begin{array}{l}116 \\
246 \\
244\end{array}$ & $\begin{array}{l}6 \\
1 \\
1\end{array}$ & $\begin{array}{l}55 \\
40 \\
45\end{array}$ & $\begin{array}{l}31 \\
20 \\
20\end{array}$ & $\begin{array}{l}56 \\
50 \\
44\end{array}$ \\
\hline Total and means & & 8 & 53 & 28 & 53 \\
\hline Chimpanzee & $\begin{array}{l}332 \\
342\end{array}$ & $\begin{array}{l}1 \\
1\end{array}$ & $\begin{array}{l}50 \\
50\end{array}$ & $\begin{array}{l}30 \\
25\end{array}$ & $\begin{array}{l}60 \\
50\end{array}$ \\
\hline Total and means & & 2 & 50 & 27 & 54 \\
\hline
\end{tabular}

(overall mean $51 \%$ ). There were no significant differences among the species investigated in the proportions of spermatozoa surviving after freezing, and the survival rate obtained is similar to that reported by Behrman \& Sawada (1966) for human spermatozoa. Samples that had the highest percentage of spermatozoal survival after freezing generally were those that exhibited good initial quality. There were differences in sperm survival rates among males within a species; preliminary trials had revealed that rhesus No. 208, stumptail No. 1060, patas No. 226, and African green No. 116 yielded spermatozoa with a higher survival rate than others in the same groups and this result was obtained also in the present series. There was no apparent deleterious effect from the use of 
trypsin before freezing. Tests showed that alpha-chymotrypsin had an adverse effect on sperm survival after freezing; this enzyme has also been found to produce ill effects on spermatozoa when these are stored at $5^{\circ} \mathrm{C}$ for $24 \mathrm{hr}$ (Roussel \& Austin, 1967).

Sadleir (1966) recently reported observations on a single ejaculate from a chimpanzee, diluted in three types of extender for freezing. The best motility after storage for 1 to 3 days was obtained from semen extended in egg yolkcitrate with $10 \%$ glycerol, milk-egg yolk with $10 \%$ glycerol and glucose-egg yolk with $7 \%$ glycerol. No figures for post-thaw motility or survival rates were given.

The authors are indebted to Mr E. N. Fussell for his assistance in this investigation. The research was supported by Grants GM 13226 and FR 00164 from the U.S. Public Health Service.

\section{REFERENCES}

Behrman, S. J. \& Sawada, Y. (1966) Heterologous and homologous inseminations with human semen frozen and stored in a liquid-nitrogen refrigerator. Fert. Steril. 17, 457.

Polge, C., Smith, A. U. \& Parkes, A. S. (1949) Revival of spermatozoa after vitrification and dehydration at low temperatures. Nature, Lond. 164, 666.

Roussel, J. D. \& Austin, C. R. (1967) Enzymic liquefaction of primate semen. Int. J. Fert. (In press.)

Roussel, J. D., Kellgren, H. C. \& Patrick, T. E. (1964) Bovine semen frozen in liquid nitrogen vapor. 7. Dairy Sci. 47, 1403.

SAdLeIR, R. M. F. S. (1966) The preservation of mammalian spermatozoa by freezing. Lab. Pract. 15, 413.

Sherman, J. K. (1963) Improved methods of preservation of human spermatozoa by freezing and freeze-drying. Fert. Steril. 14, 243.

Sherman, J. K. (1964) Low temperature research on spermatozoa and eggs. Cryobiology, $1,103$.

Weisbroth, S. \& Young, F. A. (1965) The collection of primate semen by electro-ejaculation. Fert. Steril. 16, 229. 